\title{
FREEDOM AND REACTION: SOME OBSERVATIONS ON THE CURRENT ANTI-LABOR DRIVE
}

\author{
LeE Pressman*
}

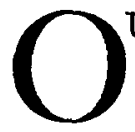

UR country is now the theater of an attack upon labor organizations, upon existing protections of the organizational process, and of collective bargaining which raises profound and basic questions.

The current attack upon labor cannot be viewed as a phase of a narrow controversy limited in scope and implications. Those concerned with the future of democracy should not fail to recognize that a free government cannot survive the destruction of the rights of labor and the elimination of the organized labor movement as an institutional force in our society.

The present anti-labor drive offers many instructive lessons which transcend the subject matter of labor. It teaches us how easy it is to create an atmosphere in which values and fundamental adjustments, written into the law after years of bitter experience, may overnight become the victims of hysteria and prejudice.

I am concerned with the easy and light-hearted manner in which it is proposed to discard deliberately reached and careful solutions to demonstrated evils besetting our industrial society. I am also concerned with the techniques whereby the rights which labor now enjoys-some embodied in statutes, others to which have been imparted constitutional protection, and still others which have come to be recognized as part of our industrial mores - are now being attacked. The techniques which are being employed deserve some attention because they will undoubtedly be resorted to when other types of civil rights which are basic to democracy are subjected to attack.

Of particular interest is the manner in which the drive against labor has paraded as a crusade for freedom.

\section{THE REDISCOVERY OF INDIVIDUAL RIGHTS}

Perhaps the most predominant characteristic of the current attack upon labor's rights is the rediscovery of the individual. This rediscovery of the individual finds reflection in a host of bills now before the Congress to alter and amend our federal labor code.

The many proposals on employer freedom of speech have as one of their

* General Counsel, Congreśs of Industrial Organizations. 
objectives the revival of the practice of individual bargaining. Under these bills the disregard by the employer of the collective bargaining agent and his dealing and negotiating with individual employees could not serve to place him in default for refusing to bargain under the National Labor Relations Act. In support of this proposal professional defenders of individual rights in Congress who have never before distinguished themselves in their defense of civil rights denounce that "collectivism" which requires the employer under Section 8(5) of the National Labor Relations Act to deal with the collective bargaining agent and with no other. The present inhibition upon individual dealing is seen as a double yoke: $x$ ) as a denial of freedom of speech to the employer, and 2) as a denial of freedom of contract to the employee.

A similar emphasis upon this theme of individual rights threads all of the major bills in which the right to strike is either suppressed or qualified. Nothing in those measures, we are assured in bill after bill, shall be construed to prohibit an individual employee from voluntarily terminating his employment.

Similarly, the various proposals now pending prohibiting the closed shop purport to seek to restore individual rights and to rescue the individual from the "tyranny" of the group.

Another instance of this emphasis upon individual rights may be found in a bill proposed by Senator Ball which amends the National Labor Relations Act to permit the individual employee not merely to present his grievance to his employer but actually to adjust and to dispose of it without the intervention of the bargaining agent. ${ }^{2}$

Finally, this theory has become the basis for undermining the Fair Labor Standards Act ${ }^{3}$ through proposals sanctioning individual compromise of wage claims under that act. ${ }^{4}$

These are but a few of a great many legislative proposals both on the federal and state level which address themselves to reviving theories of individual rights and individual bargaining.

Those who lead the attack against labor today pose as the most ardent

工 49 Stat. 449 (r935), 29 U.S.C.A. § I5I (r942). Act.

${ }^{2}$ S. $360, \S 6$, 8oth Cong. Ist Sess. (I947), amending $\S 9(9)$ of the National Labor Relations

${ }^{3} 5_{2}$ Stat. 1060 (1938), 29 U.S.C.A. § 201 (I942).

4 See H.R. 2157, $\$ 2$ (b), 8oth Cong. Ist Sess. (r947) and S. 7o, $\$ 4(f)$, 8oth Cong. Ist Sess. (I947), bills now pending to amend the Fair Labor Standards Act. Compare Brooklyn Savings Bank v. O'Neil, 324 U.S. 697, 707 (I945), rehearing den. 325 U.S. 893 (I945), "No one can doubt but that to allow waiver of statutory damages by agreement would nullify the purpose of the [Fair Labor Standards] Act."? 
champions of the rights of the individual. Anti-labor bills are regularly introduced by unctuous guardians of freedom.

Those who are familiar with the evolution of individual rights theories in labor relations certainly cannot be deceived by these latter-day conversions to freedom. Let us not forget the days when employers vigorously argued that women should be permitted to work sixteen hours a day and that to prohibit such forms of exploitation by statute was an interference with individual rights.

When labor organizations first acquired a measure of popular recognition the open-shop movement launched the protest that the freedom of the individual to contract for himself was being subverted to the everlasting detriment of our system of free enterprise.

The rhetoric which one hears again today about the loss of individual freedom, the loose oratory about the tyranny of unions, must be identified for what it is-a dangerous attempt to clothe exploitation in an attractive slogan. Reams have been written about the illusory freedom of the individual in dealing with his employer. Now more than ever it is important to emphasize the truth that individual freedom in our economic life finds its broadest expression through the encouragement and the fostering of employee self-organization and collective bargaining.

As far back as 1898 the Supreme Court noted that in dealings between the employer and the individual employee there is no freedom of contract; that, "in other words, the proprietors lay down the rules and the laborers are practically constrained to obey them."s

Congress itself announced a like finding in the Norris-La Guardia Act that "under prevailing economic conditions.... the individual unorganized worker is commonly helpless to exercise actual liberty of contract and to protect his freedom of labor, and thereby to obtain acceptable terms and conditions of employment. ... ." The Senate Committee report on the proposed National Labor Relations Act declared that "the second major objective of the bill is to encourage, by developing the pro-

5 Holden v. Hardy, I69 U.S. 366,397 (I898). This fact, first adduced by the Supreme Court to sustain a state statute limiting the miners' work-day to eight hours, became the basis of succeeding decisions: Knoxville Iron Co. v. Harbison, I83 U.S. 13 (rgor), requiring cash redemption of evidence of indebtedness issued in payment of wages; Patterson v. Bark Eudora, I9० U.S. I69 (I9०3), forbidding advance payment of seamen's wages; McLean v. Arkansas, 2II U.S. 539 (rgog), prohibiting agreements to pay miners on the basis of the weight of screened coal; Chicago, B. \& Q. R. Co. v. McGuire, 2I9 U.S. 549 (igIr), prohibiting contracts limiting liability for injuries to employees; Bunting v. Oregon, 243 U.S. 426 (1917), limiting hours of work of factory employees; N.Y. Central R. Co. v. White, 243 U.S. x88 (I9x7), sustaining workmen's compensation laws; West Coast Hotel Co. v: Parrish, 300 U.S. 379 (1937), sustaining a minimum wage law.

${ }^{6} 47$ Stat. 7o (I932), 29 U.S.C.A. § I02 (I942). 
cedure of collective bargaining, that equality of bargaining power which is a prerequisite to equality of opportunity and freedom of contract." 7

The National Labor Relations Act was based upon the slowly accumulated experience through depression, exploitation, and misery that the bargaining impotence of the individual rendered his freedom nugatory and that true freedom does not begin until bargaining equality obtains. ${ }^{8}$

In sustaining the constitutionality of the National Labor Relations Act, the Supreme Court said:

Long ago we stated .... that a single employee was helpless in dealing with an employer; that he was dependent ordinarily on his daily wage for the maintenance of himself and family; that if the employer refused to pay him the wages that he thought fair, he was nevertheless unable to leave the employ and resist arbitrary and unfair treatment; that union was essential to give laborers opportunity to deal on an equality with their employer.9

When legislative proposals based on individual-rights theories do not actually involve plans for outright substitution of individual for collective bargaining, they involve the creation of a parallel system. They would, either through the grievance procedure, as indicated above, or otherwise, sanction a form of individual bargaining. The Supreme Court has recognized that individual bargaining is a destructive parasite upon collective bargaining and cannot coexist with it under either the Railway Labor Act or the National Labor Relations Act. ${ }^{\mathrm{I0}}$ In J. I. Case Co. v. NLRB, ${ }^{\mathrm{Ix}}$ the Court held that:

The very purpose of providing by statute for the collective agreement is to supersede the terms of separate agreements of employees with terms which reflect the strength and bargaining power and serve the welfare of the group. ${ }^{x 2}$

Accordingly, it held that the institution of collective bargaining puts an end to the use of individual contracts with. the employees. In Order of Railroad Telegraphers v. Railway Express Agency, ${ }^{13}$ the Court overruled the employer's contention that individual contracts made after the collective contract superseded the latter, saying:

If this were true, statutes requiring collective bargaining would have little substance, for what was made collectively could be promptly unmade individually. ${ }^{14}$

7S. Rep. 573, 74th Cong. Ist Sess., at 3 (I935).

${ }^{8} 49$ Stat. 449 (1935), 29 U.S.C.A. \& I5I (1942).

9 NLRB v. Jones \& Laughlin Steel Corp., 30r U.S. I, 33 (r937), quoting from Mr. Chief Justice Taft in American Steel Foundries v. Tri-City Central Trades Council, 257 U.S. 184 , 209 (I92I).

s0 Order of Railroad Telegraphers v. Railway Express Agency, 32 I U.S. 342 (I944); J. I. Case Co. v. NLRB, 32 I U.S. 332 (1944).

II 32 I U.S. 332 (I944).

$x$ Ibid., at 338 .
${ }^{13} 32$ I U.S. 342 (1944).

${ }_{4}$ Ibid., at 346 . 
Turning to the employer's further contention that the particular situation which the employer and the employees had dealt with by separate agreement was "unique," the Supreme Court pointed out that:

.... exceptional situations often have an importance to the whole because they introduce competitions and discriminations that are upsetting to the entire structure. Hence effective collective bargaining has been generally conceded to include the right of the representatives of the unit to be consulted and to bargain about the exceptional as well as the routine rates, rules, and working conditions..... But the Company did not observe the right of the representatives of the whole unit to be notified and dealt with concerning a matter which from an employee's point of view may not be exceptional or which may provide a leverage for taking away other advantages of the collective contract. ${ }^{\mathrm{X}}$

In the J. I. Case and the Order of Railroad Telegraphers cases the Supreme Court ruled out not only those individual contracts which lower the collective standard but also those which secure "better terms than those obtainable by the group."16

The practice and philosophy of collective bargaining looks with suspicion on such individual advantages ..... advantages to individuals may prove as disruptive of industrial peace as disadvantages. They are a fruitful way of interfering with organization and choice of representatives; increased compensation, if individually deserved, is often earned at the cost of breaking down some other standard thought to be for the welfare of the group, and always creates the suspicion of being paid at the longrange expense of the group as a whole. 77

Is Ibid., at 346-47.

${ }^{26}$ J. I. Case Co. v. NLRB, 32I U.S. 332, 338 (I944).

${ }^{17} \mathrm{Ibid}$., at $338-39$. The dangers of paralleling the collective bargaining system with individual bargaining were quite clear to the framers of the National Labor Relations Act. The House Committee said: "Section 9 (a) incorporates the majority rule principle..... As a necessary corollary it is an act of interference under sec. 8( $\mathrm{r}$ ) for an employer, after representatives have been so designated by the majority, to negotiate with individuals or minority groups in their own behalf on the basic subjects of collective bargaining. .... There cannot be two or more basic agreements applicable to workers in a given unit; .... If the employer should fail to give equally advantageous terms to non-members of the labor organization negotiating the agreement, there would immediately result a marked increase in the membership of that labor organization. On the other hand, if better terms were given to non-members, this would give rise to bitterness and strife, and a wholly unworkable arrangement whereby men performing comparable duties were paid according to different scales of wages and hours. Clearly then, there must be one basic scale, and it must apply to all:" H.R. Doc. Ir47, 74th Cong. Ist Sess., at 20 (1935).

Similarly the Senate Committee reported: "Majority rule carries the clear implication that employers shall not interfere with the practical application of the right of employees to bargain collectively through chosen representatives by bargaining with individuals or minority groups in their own behalf, after representatives have been picked by the majority to represent all." S. Rep. 575, 74th Cong., Ist Sess. at I3 (I935).

The position taken by Congress was based on the testimony of experts. During the hearings preceding the enactment of the act, Mr. Francis Biddle, who at that time was chairman of the old National Labor Relations Board under Public Resolution No. 44, testified: "The experience of this Board in the cases before it has indicated that the insistence of the employer on 
If it is inadmissible to substitute individual bargaining for collective bargaining, it is likewise inadmissible to substitute for the right to strike the "right" of the individual to quit work.

The conditions of modern industry and the dependence of the worker upon his job for sustenance rob the "right" of the individual to quit work of any meaningful content. It is only when the individual can quit in concert with his fellows that meaning for the individual accrues to the right to quit.

Moreover, it is fundamentally inconsistent to protect the right to bargain collectively but to deny the right to quit collectively. ${ }^{18}$

The plain fact is that collective bargaining without the right to strike is meaningless. If a labor organization cannot implement its bargaining program through a concerted cessation of work, then the right to bargain is no real right. If any proposal of a labor organization were subject to the unilateral veto of the employer without the correlative right of the union to strike in support of its proposal, a situation would be present in which collective bargaining would be basically undermined by individual bargaining.

Most eloquent in defense of individual rights are those who oppose the closed shop. Current opposition to the closed shop on the basis of individual freedom must be recognized as a part of a historic attempt to harness the semantics of freedom to a fundamental anti-union purpose. As the LaFollette Committee noted:19

These "open shop" statements of the employers' associations were always phrased in a lofty vein. They opposed the closed shop, they said, because it infringed upon the liberty of the workingman to choose his employment regardless of union affliation. They called upon the public to support them in their effort to free the average workingman from the necessity of joining unions. Sometimes, in fact, they invited unions to lay aside their demands for the closed shop, intimating that their own activities would have no further reason for existence if their invitation were accepted.

That this purported solicitude for the freedom of the workingman from the closed union shop was not in fact the real reason for the existence of these employers' associations, nor indeed the motive for their activities, has been amply demonstrated in

individual bargaining has been for the purpose of interfering with collective bargaining and not for the purpose of preserving the individual liberty of contract of the American workman." Hearings before the Senate Committee on Education and Labor on S. 1958, 74th Cong. Ist Sess., at 8I (1935).

${ }^{18}$ The protection of the right to bargain collectively but the denial of the right to quit collectively is not only an instance of an anti-labor use of individual rights theories, it is also illustrative of the technique of attaching to rights conditions fatal to their effective exercise, discussed in Part II of these remarks.

s S. Rep. 6, 76th Cong. Ist Sess., Part I, at 54-55 (1939). 
previous reports of this Committee. It has there been shown that under the banner of the "open shop" the employers' associations created an organized front against collective bargaining and sought to destroy or weaken all union organizations regardless of whether the closed shop was achieved in any given case. Illuminating analyses of the semantics of the closed and open shop and what the terms really meant to the employers' associations which used them may be found in this Committee's report on the Associated Industries of Cleveland, and in the testimony given by employers' association leaders in Los Angeles. Ostensibly the "open shop" doctrine meant only that there should be no discrimination against non-union workers in hiring, but, in practice, adherence to the open-shop doctrine required that the employer discriminate against union workers in hiring. Said the American Plan-Open Shop Conference in I925, "in the true sense of the American Plan Open Shop he (the employer) cannot maintain Ioo per cent union crew in any department or in any craft of his business." Attainment of this objective necessarily required discrimination against union men, and the use of labor espionage or other devices to ascertain the extent of union affiliation in the shop or plant. Collective bargaining encouraged union membership and was therefore implicitly condemned. Some employer groups, in the name of the open shop, even went so far as to forbid the hiring of union men at all. This was the case in Los Angeles at the time of the investigation by the United States Commission on Industrial Relations.

It was long ago realized when employers raised the individual-rights argument against the closed shop, that the right of the individual in modern industrial relations consists primarily of the right to sell his labor at a cheaper price than another. It was recognized then that those who championed the individual's "right to work" were in fact using a fictional freedom to glorify industrial autocracy and to justify the employer's right to hire and fire on his own terms. ${ }^{20}$

Professor Robert L. Hale of Columbia University Law School has aptly analyzed the type of individual freedom which has lately won so many defenders:

If a man wants to work in a steel plant, he does not just go out and work according to his own ideas about how it should be worked; he has to join an organization. Normally, in the case of a steel plant, he becomes an employee of a steel company, and then he has no freedom as to the details of his work whatever; he is a non-voting member of a society. Now, if he belongs to a union in a closed-shop industry, it is perfectly true he has no freedom to work without being a member of the union, but he has a little more freedom through the brotherhood of his union against the restraint imposed upon him by the employer.

Now of course, any system of organization is liable to have faults at times. .... Government of any sort has certain evils, or may have at particular times, but the only alternative is anarchy, where the evils would be much greater. If he is subject to be

${ }^{20}$ The distorted use of freedom concepts in the closed-shop controversy has been frequently commented on. See, e.g., Brooks, When Labor Organizes 68-69 (1938); Catlin, The Labor Problem 420-2I (r935); Hoxie, Trade Unionism in the United States rgo-95 (I936). 
governed by the rules of his union he presumably has a little more control over what those rules are than if he is governed solely by the rules laid down by his employer. ${ }^{2 x}$

Senator Ball, who is perhaps the leading and the most vocal exponent of the new freedom of the individual, has recently suggested that the impairment of freedom of contract involved in prohibitions upon yellowdog contracts is indistinguishable from the impairment of such freedom resulting from prohibitions upon union security contracts. This suggested comparison, I submit, is analytically indefensible. Moreover, it involves a disregard of the realities of modern industrial life which can only be characterized as wilful or naĩve.

Revival of the individual-rights issue comes at a time when in fact the individual, as the result of the increasing growth of monopoly, is more powerless than ever before in our history to exercise industrial freedom outside of a labor organization. The current campaign for individual rights is a campaign to destroy individual freedom, not to enlarge it.

\section{CONDITIONING THE EXERCISE OF RIGHTS}

A second type of anti-labor approach involves a claimed concern with preserving rights. This approach is also instructive because it widely characterizes many forms of legislative attacks upon popular liberty.

This second approach pays lip service to a right but attaches such conditions to its exercise as to make it meaningless. Practitioners of this approach invariably contend that they are vitally interested in preserving the right and have merely devised a means for its "orderly" exercise in order to neutralize the objections of those who would abolish it altogether. This approach is implemented in two ways. First, it is proposed to impose conditions upon the exercise of the right which would hamper the free enjoyment of the right. This type of proposal requires the payment of the kind of price as a condition to the exercise of a right which inevitably weakens its value.

Most of the proposals of this nature draw upon delay to achieve their purpose.

It is peculiarly true in labor relations that time is of the essence. A right frequently can be made valueless because its exercise must be deferred. In labor relations we are dealing with a highly perishable status quo. Delay can do as much injury to employee rights as the most forceful kind of employer misconduct. Let me give a few examples.

The National Labor Relations Board has for years been denied ade-

${ }^{2 x}$ Hearings before Senate Committee on Education and Labor on S. 2926, 73d Cong. $2 d$ Sess., at 5 I (1934). 
quate appropriations to perform its mounting tasks. As a result today it takes about a year to process an unfair labor practice case from charge to board decision. Court review may consume another eighteen months. It requires no strenuous argument to point out that during periods of time such as these a union which has suffered employer aggression may well be placed as a result of the lapse of time into a position wherein rights which the law affords on paper will in fact serve as no real protection. The wounds which an employer inflicts upon a union through discriminatory discharges, the establishment of a company union, or a refusal to bargain, may well become fatal if relief is a year or two in coming.

The same is true in representation cases. At the present time because of the board's diminished staff a representation case requires some six to eight months for processing. A petition may have been filed when the impulse of self-organization was quick but under the board's present time limitations the order for an election may be applied to an entirely changed situation. A new electorate may be present, new considerations may have supervened. The passage of time may well serve to rob the right to freedom of choice of vital content.

The persistent Congressional practice of starving labor agencies, of slowing down the administration of labor laws, must then be identified as a part of the technique by which rights are granted but their enjoyment stultified through the application of hostile conditions.

The use of delay to frustrate freedom of choice is involved in proposals which would provide for direct review of Labor Board certifications. Under the National Labor Relations Act at present an employer may only challenge a certification by refusing to bargain with the certified union. ${ }^{22}$ It has been recognized that to permit court review by direct appeal of board certifications would involve destructive delays. ${ }^{23}$ This would be an easy way of granting the right of freedom of choice but of, in fact, undermining it by endless court review.

Yet it has been proposed ${ }^{24}$ to make every certification the subject of judicial review at the instance of any individual in the bargaining unit. To create a mechanism as this provision does, which will delay the designation of a bargaining agent for a period of a year or more, is a true negation of the right to freedom of choice. Moreover, it can only serve to stimulate industrial unrest.

The same technique is used in cooling-off proposals limiting the right

22 Myers v. Bethlehem Shipbuilding Corp., 303 U.S. 4I (1938); AFL v. NLRB, 308 U.S. 40I (1940); Inland Empire District Council v. Millis, 325 U.S. 697 (1945).

${ }^{23}$ Report of Senate Committee on Education and Labor on S. 1958, 74th Cong. Ist Sess., at 5-6 (1935).

${ }^{24}$ S. $360, \S 6$ (d), 8oth Cong. Ist Sess. (1947); H.R. 880, § 9(a), 80th Cong. Ist Sess. (I947). 
to strike. A recent proposal along these lines provides for a sixty-day cooling-off period. ${ }^{25}$

A union may be faced with the necessity of striking in a particular situation at some period shorter than the sixty-day period laid down in the proposal. The sixty-day period imposes upon a union all of the weakening and limiting effects which flow from an arbitrary and unnecessary prolongation of a period of fruitless conference where employer attitudes are clear. The practical facts connected with the planning and organization of a strike must be kept in mind. A strike involving thousands of workers, such as is characteristic of modern-day major enterprises, is not a project of a single day's planning. It involves a process of organization and dispensation of information and guidance so that issues may be fully understood by all workers. The maintenance of the strike depends at all times on the morale and understanding of the participants. Strikes cannot be called on one day, the men sent back the next, and then the strike continued on the third. When an employer's obstinacy is clear and the issues are sharp, employees who wish to exercise their rights cannot be kept in a state of confusion or of uncertainty. Timing of a strike, if it is to be effective, is like the timing of any operation which requires the co-ordinated efforts of many thousands of individuals. It must be accomplished at a time when all efforts are in a position to be co-ordinated and when all individuals are in a position to act most effectively.

Moreover, frequently cooling-off periods have the effect of actually prohibiting (and not merely qualifying) the exercise of the strike right. This is so because these restraints forbid the exercise of the strike right when the employer may be economically most sensitive to it. In the case of a seasonal industry the cooling-off requirement might well permit a strike only when an employer would welcome rather than be injured by it.

This impact of the cooling-off requirement is illustrative of legislative proposals of a second type. These proposals pay lip service to the right but prohibit its exercise at precisely the point where it may be most effective. This technique is used in connection with a proposed prohibition on socalled industry-wide bargaining. We are prepared to encourage collective bargaining and to sing its praises. But at the very point when bargaining might become meaningful in terms of the realities of modern industry we ropose to outlaw it. ${ }^{26}$

${ }^{25}$ S. $55, \& 3$, 8oth Cong. Ist Sess. (x947).

${ }^{26}$ See S. 133, 8oth Cong. 1st Sess. (1947), introduced by Senator Ball. Comparable to provisions limiting the scope of bargaining are those contained in many recent measures depriving the Labor Board of discretion to define broad industrial bargaining units. The most extreme of these proposals is contained in H.R. 3020 which provides in Section $g(f)(2)$ for the exclusion from a proposed bargaining unit of the employees of "any craft, department, plant, trade, 
The same technique of, on the one hand, offering assurances that workers may go out to swim but on the other hand forbidding them to go near the water is implicit in a good deal of current thinking in connection with the boycott. ${ }^{27}$ It is hardly necessary to rehearse here the long history of the "secondary" boycott and the "sympathetic" strike. It is fair to say that enlightened courts and commentators have long ago recognized that it is important to preserve the right of workers to utilize pressures against employers who enter into economic relations with an anti-labor employer. The employer who persists in supplying an anti-union manufacturer or in serving as an outlet for his product aids the latter in his fight against the union. It is not accurate to describe an employer who serves this role as neutral. Nor is it justice to require employees to work for an employer who seeks to benefit from the sweat-shop conditions maintained by an antilabor union manufacturer.

If we are prepared to protect the rights of workers to apply economic pressure to an unfair employer, we cannot withdraw our protection of such pressures at the point when they can become truly effective, namely, when they are directed at those employers whose economic activities support and are supported by the anti-labor employer.

I have referred to the practice of preserving a right but attaching to it conditions fatal to its effective exercise as a technique. It should be recognized as such. Increasingly in the area of civil rights we note the growth of this type of formula. We do not suppress the right to vote, we merely require a prohibitive price in the form of a poll tax as a condition to its exercise. We do not deny Negroes the right to vote in a general election, we merely bar them from primaries, the area in which the right has meaning.

It seems to me that we must recognize that there is a fundamental evasion in the practice of appearing to preserve a right and creating the conditions under which it cannot be effectively exercised. In the field of labor relations this fundamental inconsistency has become quite apparent. In some cases it springs from an ignorance of the realities of labor relations, from a lack of knowledge of the conditions under which rights must be exercised in order to be effective. In many cases, however, a tremendous

calling, profession or other distinguishable group." The justification for this proposal, which would obviously destroy collective bargaining, is stated to be, in the Report accompanying H.R. 3020, "to assure full freedom to workers." In connection with most anti-labor proposals there is frequently linked with the professed concern for freedom, a synthetic nostalgia for the cozy relationships of a handicraft economy. This type of appeal forcibly reminds one of the appeal used by Hitler to destroy trade unions in Germany.

${ }_{27}$ See, e.g., S. 55, $\$ 204(\mathrm{a}-\mathrm{I})$, 8oth Cong. Ist Sess. (I947). 
conscious deception is involved. And we cannot build decent labor relations on deception.

\section{THOSE WHO ENJOY FREEDOM MUST ASSUME RESPONSIBILITY}

There is a third formula upon which the drive against labor's rights rests. This formula, too, leans heavily on a claimed concern for the preservation of freedom. The third type of formula gives rise to proposals not to regulate labor's rights but to regulate labor organizations themselves. The justification for this type of program is that since labor organizations enjoy a great deal of freedom and exercise their freedom they should be made "responsible." Indeed adherents of this school insist that labor organizations should be grateful for and should embrace the regulations which they propose since it is claimed they are a means of actually preserving freedom.

No one can quarrel with the proposition that those who enjoy'rights should assume responsibilities. However, one must be extremely careful that the "responsibilities" which are sought to be imposed are not of a type which would frustrate the enjoyment of the right.

Typical of the group of restraints proposed in this area is Section 203 of the Ball-Taft-Smith Bill ${ }^{28}$ which purports to deal with the problem of union responsibility. Section 203 proposes the following:

a. Suits based on collective bargaining contracts are brought within the jurisdiction of the federal courts without regard to any of the normal jurisdictional requirements such as diversity of citizenship or minimum amount in controversy.

b. A union is made responsible not merely, as the present law provides, ${ }^{29}$ for those acts of its committee members and other minor or major officials which the union authorizes or approves, or ratifies, but in addition, for any acts of such "agents" regardless of whether the specific acts were authorized or approved by the union.

c. Permits suit against a union in any district in the country in which the union has any such "officers or agents."

d. Declares that any employee who participates in a strike in violation of an agreement and without approval of the union shall lose his status as employee under the National Labor Relations Act.

This proposal is offered on the ground that its purpose is simply to "make unions suable" so that their collective bargaining obligations may be enforced against them. It is based upon an assumption which is wholly questionable and carries implications completely unfair to labor. The assumption underlying the campaign for this proposal is that unions and unions alone frequently violate collective-bargaining agreements. The

${ }^{28}$ S. 55, 80th Cong. Ist Sess. (I947). $\quad{ }^{29} 47$ Stat. 7 I (I932), 29 U.S.C.A. § I06 (I942). 
objective facts do not support the assumption of this legislation that there is a record of union irresponsibility.

In not one of the major CIO strikes of 1946 was there a violation of a collective-bargaining contract or any other type of obligation. In contrast, it was the General Motors Corporation which rejected the award made by a fact-finding board appointed by the President; it was the United States Steel Corporation which rejected a settlement suggestion of the President himself; and it was the Westinghouse Corporation which was denounced by two of our nation's foremost labor experts for its provocative and unreasonable prolongation of a strike.

It should be realized that every one of the thousands of arbitration awards each year which uphold union grievances is a decision that an employer has violated a contract. On the record, therefore, there are hundreds of proven employer violations for each alleged union violation.

Labor unions do not urge these facts as a basis for any legislative proposal to make lawsuits against employers more frequent in labor relations. What is significant is that these considerations indicate that supporters of proposals such as that contained in Section 203 of the BallTaft-Smith Bill are seeking mainly to establish a false public impression unfavorable to unions. Labor does not seek to create a counter-impression nor does it offer legislative counter-proposals because it could not seriously be disputed that whether a union or an employer is a contract violator, court litigation will not establish good labor relations.

Anyone familiar with labor problems recognizes that a lawsuit over a collective-bargaining agreement is the simplest and most effective way to destroy harmonious labor relationships. Employers and labor organizations with a bona fide desire to live in peace and harmony strive in every way possible to free themselves of litigation as the answer to their differences. That is why collective-bargaining contracts have developed so extensively the details of the grievance machinery and arbitration as a sensible and expeditious way to settle the hundreds of problems that may arise each week and month in the administration of a labor contract in a large plant.

There can never be good relations between an employer and a labor organization if a lawsuit is the end product of breach of a collectivebargaining agreement. Those who would invite the parties to a collectivebargaining relationship to substitute the lawsuit for the grievance procedure must be condemned as disrupters and trouble makers.

There is still another significant consideration to be recognized in the effect of this proposal. It establishes the union as a legal entity in the eyes of the federal court, without regard to and without conformance to the 
form, status, and procedure which may be prescribed by the respective state jurisdictions. In substance it gives to the unincorporated associations which are labor unions a special type of federally created status. It is a long and significant step in the direction of federal incorporation. It is a step which is in no way matched by any similar movement with respect to corporations. It is a step which is subject to all of the frequently voiced and well-recognized objections to federal incorporation.

Two of the detailed and purportedly "incidental" provisions of this section of the Ball-Taft-Smith Bill substantially expose the true effect of this section. One of these is a subdivision permitting suit to be brought against a labor organization not merely in the judicial district in which it maintains its principal office but in any district in which its "officers or agents". are located. A clearer invitation to widespread harassment of labor organizations can scarcely be conceived. Any national union has groups of members organized into locals throughout the country, many in isolated areas far distant from the main office of the organization. Each of these local groups, their committees, their minor officials, may for some purpose be deemed to be acting for the entire organization. The provisions of this section permit the filing of law suits against the entire national organization in any part of the United States where this may be the situation. The national organization may be called upon to retain or dispatch counsel, prepare evidence, try law suits in all these parts of the country at the whim of the employer who may wish thus to drain the union's treasury.

The other provision which substantially exposes the true effect of this section of the Ball-Taft-Smith Bill is that which makes the union responsible for the acts of its "agents" regardless of whether those acts have been specifically authorized or approved.

This is union "responsibility" with a vengeance. It turns the clock back to a period in which the very existence of a union was regarded as a "conspiracy." Any action by any member or minor officer anywhere could be treated as an act in furtherance of the conspiracy and all of the members made to suffer upon the theory that they all were engaged in the "conspiracy."

Theories of responsibility of this type made union busting relatively easy. It was relatively simple for an employer to plant in the union ranks an agent whose functions would be to provoke and instigate activities which might later become the subject of attack upon the union treasury. A background of this nature gave rise to Section 6 of the NorrisLaGuardia $\mathrm{Act}^{30}$ which declared that unions were not to be regarded as ${ }^{30} 47$ Stat. $7 \mathrm{I}$ (I932), 29 U.S.C.A. § 106 (1942). 
responsible for any acts other than those actually authorized or approved or ratified..$^{3 \mathrm{I}}$ It is this rule which the present section of the bill proposes to alter. ${ }^{32}$

Even in the absence of an employer spy it must be realized that a section attempting to impose liability on unions in the act of any "agent" is grossly unfair. Any truly democratic union has an extremely large number of "agents." Grievance-committee men are authorized agents in the negotiation of grievances. Locally elected officers are authorized agents for the administration and leadership of their locals. Dozens of committees of union members exist for various purposes in each local union. During a strike there are picketing committees, food committees, negotiating committees, and many others.

It has always been the aim of anti-union employers to seek to attack the union or to tie up the union's funds on the basis of any minor alterca-

${ }^{3 x}$ The Senate Committee Report made extremely vivid the need for Section 6: "In most cases where strikes occur involving a great many employers and employees and covering a comparatively large territory, there are often unlawful acts committed in the way of injury to property or to persons. It is not the intention of the bill to protect anybody, whether he be employer or employee, from punishment for the commission of unlawful acts either as against property or persons. But no person or organization should be held thus liable unless he or it caused the unlawful act or participated in it or ratified it. It has often occurred that employers themselves have secured the services of detectives who, under the guise of labor men, have gained admission into labor unions. When this happens these detectives are usually doing everything within their power to incite employees who are on strike to commit acts of violence, and such detectives, contrary to the definite instructions of labor union leaders, sometimes commit unlawful acts for the express and only purpose of laying the foundations for injunctive process, of bringing discredit upon the union, and of making its officers and members liable for damages. In case of a strike, where the officers of the labor union are doing everything within their power to prevent acts of violence from being committed by any person, the law should fully protect them and save them and the members of their organization who are following their advice from liability in damages because of unlawful acts of persons who are either directly or indirectly connected with those who are trying to defeat the purposes of the strike .... why should an officer of a labor union, who has specifically advised members that violence must be avoided, become responsible for the hot-headed action of some member in perhaps assaulting a strike breaker? Again, the relationship between officers and members of labor unions and other members is not that of employer and employee. The officers chosen by a union are not employers of the membership. They have no control over their associates based upon the power of determining whether or not they will employ them. It may be accepted that if a group associated in common activities becomes controlled by a lawless majority, it may be necessary for law-abiding men to dissolve their association with lawbreakers; but the doctrine that a few lawless men can change the character of an organization whose members and officers are very largely law-abiding is one which has been developed peculiarly as judge-made law in labor disputes, and it is high time that, by legislative action, the courts should be required to uphold the long established law that guilt is personal and that men can only be held responsible for the unlawful acts of associates because of participation in, authorization or ratification of such acts. As a rule of evidence, clear proof should be required, so that criminal guilt and criminal responsibility should not be imputed but proven beyond reasonable doubt in order to impose liability." S. Rep. $163,72 d$ Cong. Ist Sess., at $19-21$ (I932).

${ }^{32}$ The rule of liability of the type proposed in S. 55 was recently rejected by the Supreme Court in United Brotherhood of Carpenters and Joiners v. United States, 67 S.Ct. 775 (I947), as inconsistent with Section 6 of the Norris-LaGuardia Act. 
tion or scuffle on a picket line or on the basis of some minor infraction by an individual member or local grievance man. This section would now make that possible.

As a matter of fact the section is particularly ironic in the light of the frequent insistence by many of the same groups which urge provisions of this type that there is insufficient democracy in American unions. The simple fact is that the more democracy there is in a union the more "agents" the union necessarily has. Such a consequence is extremely desirable. But if the financial responsibility of the union is to be expanded to include liability for actions of all these "agents," even when the acts are not authorized or ratified, then this bill is actually encouraging and insisting that in self-protection the union impose greater centralization so as to confine authority and agency only to the highest and most restricted levels of leadership. That is contrary to the principles of democratic unionism and should be regarded as contrary to the principles of desirable public policy.

Grimly pursuing the "responsibility" theme, the proposed section in a final clause declares that where an employee participates in an unauthorized stoppage he "shall lose his status as an employee" for purposes of the National Labor Relations Act.

The claimed purpose of this clause is to protect unions against stoppages which they themselves do not authorize. Many union contracts now provide that an employee who engages in a stoppage in violation of contract may be discharged as a penalty. This is a clause of a type which may be quite sound where an employer and union feel that a collective bargaining relationship is such as to make such action a desirable means of enforcement. A statutory approach which arbitrarily assumes that such a penalty is necessary and desirable in all instances and under any circumstances would be in itself dangerous and undesirable.

The proposal, however, goes far beyond even that. It penalizes not merely the employee but also the very union against whose orders the employee is rebelling. The proposal specifically includes a loss of status as an employee under Section 9 of the National Labor Relations Act. Presumably, therefore, if a majority of the employees at a given plant strike in violation of union policy then they lose their status as employees in determining representation and the union loses its collective bargaining rights.

Recent history offers a grim reminder that appeals in the name of freedom can cloak an intent to destroy freedom. Much of the current antilabor campaign must be analyzed for what it basically is-the resort to the arguments of freedom for the purpose of making repression palatable. 